\title{
The Problems and Challenges Facing E-Marketing in the Kurdistan Region of Iraq
}

\author{
Nasreen K. Othman ${ }^{1}$ and Luqman Q. Abdulrahman Ruandzy ${ }^{2}$ \\ ${ }^{1}$ Department Business Management, Erbil Technical Administration Institute, Erbil Polytechnic University, University, \\ Erbil, Kurdistan Region - Iraq \\ ${ }^{2}$ Department of physiotherapy, College of Health Sciences, Hawler Medical University, Erbil, Kurdistan Region - Iraq
}

\begin{abstract}
With technological developments and the emergence of the Internet, other methods of trade had to emerge that differ from traditional commerce, so what is known as e-commerce appeared, and to keep pace with these developments it was necessary to know what e-commerce is and how to use it, it is the process of buying or selling products through electronic means, such as The Internet or other electronic services, and the need for e-commerce emerged from the need to use computers more efficiently in banks and companies, and with the increase in competition, it was imperative for organizations to work on ecommerce in order to increase customer satisfaction and exchange information. In our research, we prepared a questionnaire containing a set of questions and gave them to more than 150 people from different categories and disciplines to find out their opinions on this topic, and we benefited from the data analysis program (SPSS). Then we collected the data and then wrote the conclusions and reached what we reached, and then we made suggestions to address the problems faced by digital marketing. Since the outbreak of the Coronavirus (Coved 19), more than $85 \%$ of customers around the world are shopping via the Internet, so there is no doubt that despite the setbacks in various sectors around the world; On top of them are the commercial sectors, but there are many other sectors that have made the most of this crisis, and perhaps the most prominent of them is "e-commerce", which has witnessed an increasing demand in light of customers' fear of being in crowded places.
\end{abstract}

Keywords- Buying, E. Marketing, E. Shopping, Network Marketing, Selling.

\section{INTRODUCTION}

The Internet is a wide system for the consumer shopping, which provides the consumer with instant information of lowcost in a short time, which is one of the most striking features of the Internet; whereas the Internet provides information used by the buyer, such as products that facilitate access to information on their products to easily search for the product, and it is a self-service for the availability of specific information on demand, in addition to information about prices and products (Kotler, 2007), as merchants face many challenges on the Internet in increasing the number of ecommerce public, where customers must feel that information they show is safe and confidential (Hutt \& Speh, 2007).

(Brich, 2000) indicates that evolution and innovation in information technology contributed to dissolving boundaries between states making it easier to trade for goods and service in a better way than traditional methods of sale. Each of Vercho poulas, et al, (2001, p142) and Ward \& Lee (2001, p6) agreed to examine the reasons that invites consumers to do online shopping activity lies easy that the consumer can find many products online, and the availability of 24 hours service and save time for the consumer and meet the increase in record numbers. Both Wolfinbarger \& Gilly (2002, p 34-35) and Modahi (2000) regard that online shopping is efficient, rational and customers can shop fast. During this process of acquiring goods and services over the internet, the attitude and preferences of the family evolve, change and adopt to what best suits its interest that became influenced by other stimulus.

This study has found (Brown, 2003; Monsuw,2004) that the trends and tendencies of consumers towards buying online is not only affected by the ease of use of the Internet and the benefit and pleasure that the user from the Internet, but also influenced by other factors such as: the characteristics of the consumer, product characteristics, consumer experience, the availability of Confidence in buying online, and consumer attitudes towards buying have no significant effect on the tendency of consumers to buy products online, while showing that both the type of product and previous purchases made by the consumer and type affect the intention to purchase online. Therefore, the phenomenon of e-shopping has been chosen to determine the magnitude of the problem and study it in depth so as to benefit from reading social science in the Kurdish society, from the application of its results, which may show them some aspects to help formulate effective policies in shopping and consumption.

The following are the objectives of the study:

- The study aims to understand the consumer buying behavior while shopping online.

Polytechnic Journal of Humanities and Social Sciences

Volume 1 No. 1 (2020); 08pages; DOI: 10.25156/ptjhss.v1n1y2020.pp24-31

Received 30 January 2020; Accepted 7 February 2020; Regular research paper: Published 30 June 2020

Corresponding author's e-mail: luqman.qader@epu.edu.iq

Copyright () 2020 Nasreen K. Othman and Luqman Q. Abdulrahman Ruandzy. This is an open access article distributed under the Creative

Commons Attribution License (CC BY-NC-ND 4.0) 
- The study aims to identify positive and negative antecedents of consumer attitudes towards online shopping.

- To measure the relationship between income and gender are the two important factors identified that may have considerable impact on consumers' perception towards online shopping.

\section{LITERATURE REVIEW}

Many tools used in this study are depending on the nature of each objective, different assumption, so most studies used questionnaires and interviews. In terms of curriculum, most studies have used descriptive analytical.

The study (Littlefield \& cook, 2000) found that the internet information and awareness of internet use and age are factors that affect the efficiency of the internet to purchase. So we can mention some of those studies as follows:

Phau, et al., (2000) found that the qualities of different products and services will influence decisively in the burger or consumer choice about choosing between purchasing via shops or online.

Miley (2001) found that there is a statistically significant relationship between the desire to use the website to purchase each of the qualification and job class an annual house hold income, marital status and age.

The most important results of the study (Teo, 2001) stated that that education and age variables were critical factors in differentiating between the participants in terms of variation in stress. Another important result of the study (Dan, et al., 2003) confidence and trust are essential components of successful trade relations in the field of consumer electronic trade.

Brown (2003) found that all of the previous purchases and product type affect the impulse buy online.

The results of the study (Wolin \& Korgaonkar, 2003) indicated that males have more positive attitudes toward female internet ads.

Constantinides (2004) found dividing factors affecting online shopping behavior into three groups (job factors, psychological and marketing mix).

While the results of the study (Jayawardhena, 2004) internet user personal values affect morally positive trends about buying online.

One of the most important results of the study (Monsuwe, 2004) stated that the consumer trend towards e-procurement not affected just as easily use the internet, but affected by consumer qualities and characteristic of the products, and past experience for the consumer.

Based on the aforementioned, the following hypothesis was drawn:

H1: There is a correlation between the questionnaire of electronic shopping in the information age and the components of the questionnaire on consumer trends of the sample members.

$\mathrm{H} 2$ : There were statistically significant differences between the average scores of the sample on the advantages and disadvantages of electronic shopping in the following variables (Education level of male and female, age, position, monthly income).
H3: There were statistically significant differences between the average scores of the sample in regards to the steps involved in online shopping in the information age according to the following variables (education level of male and female, age, position, monthly income).

H4: The degree to which the different factors affect online shopping is different from one factor to another in the information age.

H5: The degree to which the different factors affect consumption trends of the family is different from one factor to another.

H6: The relative weights assigned to the priority of the consumption trends are different from each other in the research sample.

\section{RESEARCH METHODOLOGY}

The scientific method used in this research is the descriptive analytical method, and it does so by providing present sample data to explain and understand the future, then make comparisons and identify the relationships between the factors and develop conclusions with the help of the data at hand. For the Data analysis we are using statistical methods through appropriate SPSS (Statistical Package for Social Science)

Because we wanted the study sample to be representative of the whole community and the results to be applicable to all with the lowest error rate, the highest degree of reliability we have chosen a nonrandom and purposive sample for this research, the number of the sample is 150 persons who do shopping online, and in these families we gave equal values to the views of the male and female as both of them are representing the consumption views of the family member.

The Independent Variable in this research (electroniccommerce in information age), with some other independent variables such as demographic variables.

They were classified into two axes:

$>$ Advantages and disadvantages of electronic shopping.

$>$ Steps involved in electronic-shopping.

The Dependent Variable in this research is (consumption trends for the individual in all three of its components "Component of knowledge, Behavioral component and Emotional component".

\section{FINDINGS AND Discussion}

Table I shows that the proportion of participants who use electronic shopping of higher adult male (57.3\%) compared with participants of the female and adult (42.7\%).

TABLE I

NUMBER OF RESPONDENTS BY GENDER

\begin{tabular}{llll}
\hline \hline & Gender & Number & Ratio \\
\hline \hline & 86 & $57.3 \%$ \\
Male & 64 & $42.7 \%$ \\
Female & 150 & $100 \%$ \\
Total & & \\
\hline \hline
\end{tabular}


Fig. 1 shows that the proportion of participants who use electronic shopping of higher adult male (57.3\%) compared with participants of the female and adult (42.7\%).

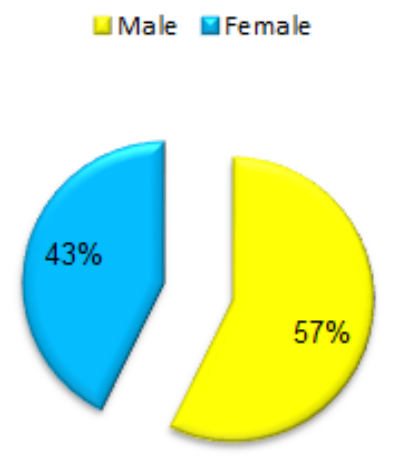

Fig. 1. Number of respondents by gender

Table II shows the highest educational level of participants obtaining a certificate (Diploma-bachelor), this shows the high level of education research sample members above the secondary/high School education.

Fig. 2 shows the highest educational level of participants obtaining a certificate (Diploma-bachelor), this shows the high level of education research sample members above the secondary/high School education.

TABLE II

NUMBER OF RESPONDENTS BY LEVEL OF EDUCATION

\begin{tabular}{lll}
\hline \hline Education level & Number & Ratio \\
\hline Secondary/ High School & 13 & $8.7 \%$ \\
Diploma-bachelor & 69 & $46 \%$ \\
Master- doctor & 68 & $45.3 \%$ \\
Total & 150 & $100 \%$ \\
\hline \hline
\end{tabular}

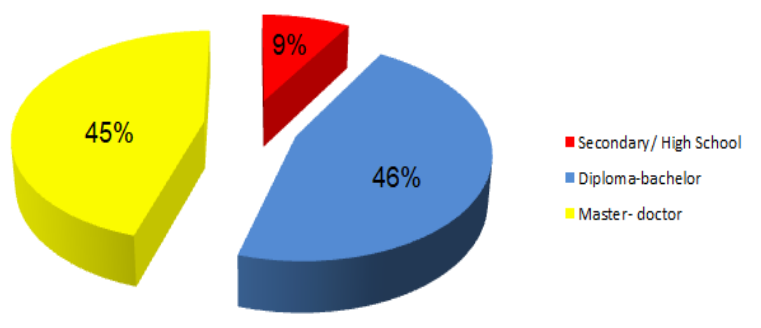

Fig. 2. Number of respondents by level of education

Table III shows that ratio $(36 \%)$ of respondents aged (45$55)$ year, followed by (30\%) of respondents aged (35-45) year. This confirms the results of the previous table that the highest proportion of respondents are obtaining the certificate (Diploma-bachelor and Master- PHD).

Table IV shows that ratio $(69.3 \%)$ of respondents work in the public sector, and ratio $(12.7 \%)$ of respondents work the Free business, followed by a straight percentage (10.7\%) and $(7.3 \%)$ are working in the Private sector and who do not work.
TABLE III

NUMBER OF RESPONDENTS BY AGE

\begin{tabular}{lll}
\hline \hline Age & Number & Ratio \\
\hline Less than 35 year & 26 & $17.3 \%$ \\
$35-45$ & 45 & $30 \%$ \\
$45-55$ & 54 & $36 \%$ \\
Great than 55 year & 25 & $16.7 \%$ \\
Total & 150 & $100 \%$ \\
\hline \hline
\end{tabular}

TABLE IV

NUMBER OF RESPONDENTS BY POSITION

\begin{tabular}{lll}
\hline \hline Post & Number & Ratio \\
\hline Private sector & 16 & $10.7 \%$ \\
Government sector & 104 & $69.3 \%$ \\
Free business & 19 & $12.7 \%$ \\
Didn't work & 11 & $7.3 \%$ \\
Total & 150 & $100 \%$ \\
\hline \hline
\end{tabular}

Table $\mathrm{V}$ shows that the more categories of monthly income of respondents was in category (900000-1200000) DI) adult ratio $(67.3 \%)$, this indicates that most respondents are high income.

TABLE V

NUMBER OF RESPONDENTS BY MONTHLY INCOME

\begin{tabular}{lll}
\hline \hline Monthly income & Number & Ratio \\
\hline Fro (300000-600000)DI & 14 & $9.3 \%$ \\
Fro (600000-900000) DI & 27 & $18 \%$ \\
Fro (900000-1200000) DI & 101 & $67.3 \%$ \\
More than 1200000 DI & 8 & $5.3 \%$ \\
Total & 150 & $100 \%$ \\
\hline \hline
\end{tabular}

Table VI shows to (84) of respondents have bought more than once from the market and represent $(56 \%)$, repeat sample shows for purchase via electronic-shopping sites to the advantages that touched them through previous experiences in electronic shopping, which confirms that they stopped buying after the first experience was low did not exceed the percentage $(18 \%)$ the proportion of respondents.

TABLE VI

NUMBER OF PURCHASE ELECTRONIC MARKET

\begin{tabular}{lll}
\hline \hline $\begin{array}{l}\text { Number of purchase in } \\
\text { electronic market }\end{array}$ & Number & Ratio \\
\hline One time & 39 & $26 \%$ \\
More than once & 84 & $56 \%$ \\
I have been dealing previously stopped & 27 & $18 \%$ \\
Total & 150 & $100 \%$ \\
\hline \hline
\end{tabular}

Table VII shows the proportion of members who prefer to pay by credit cards reached $(15.3 \%)$, the proportion of members who prefer to pay by prepaid credit card reached $(13.3 \%)$ and bank remittance $(2.7 \%)$. While the highest proportions are individuals who prefer to pay cash on delivery ratio reached $(67.3 \%)$. This shows that more than half of the 
sample using the methods of payment cash on delivery and supports this result that most respondents shop local sites that accepts deal with cash.

TABLE VII

PREFERRED PAYMENT METHODS

\begin{tabular}{lcc}
\hline \hline \multicolumn{1}{c}{ Preferred payment methods } & Number & Ratio \\
\hline Credit card & 23 & $15.3 \%$ \\
Electronic money & 2 & $1.3 \%$ \\
Prepaid credit card & 20 & $13.3 \%$ \\
Bank remittance & 4 & $2.7 \%$ \\
Payment cash on delivery & 101 & $67.3 \%$ \\
Total & 150 & $100 \%$ \\
\hline \hline
\end{tabular}

Table VIII shows the more service demand rises via the web was educational services (58\%) sample member search, this confirms that the results of the previous table that most respondents who possess a certificate (Diploma-bachelor, Master- PHD) which they use to access web sites. Unlike health service, tourism service where demand is bound by certain groups in society.

TABLE VIII

THE BEST SERVICE THAT IS REQUESTED THROUGH THE ELECTRONIC SHOPPING

\begin{tabular}{lll}
\hline \hline best service & Number & Ratio \\
\hline Health service & 30 & $20 \%$ \\
Educational service & 87 & $58 \%$ \\
Tourism and travel service & 33 & $33 \%$ \\
Total & 150 & $100 \%$ \\
\hline \hline
\end{tabular}

Table IX shows the more goods have purchased research sample members through online shopping and the top three were: (Books and references, Cosmetics and clothing, Computer programs) in the order $(23 \%, 20.6 \%, 19.4 \%)$, this confirms that the results of the previous table that most service that rise in demand across the web was educational services.

TABLE IX

MORE GOODS TO BE PURCHASED BY ELECTRONIC SHOPPING

\begin{tabular}{lll}
\hline \hline More goods to be purchased & Number & Ratio \\
\hline Computer programs & 32 & $19.4 \%$ \\
Computer and accessories & 13 & $8.7 \%$ \\
Cellular devices & 5 & $3.3 \%$ \\
Books and references & 38 & $23 \%$ \\
Electric devices & 9 & $6 \%$ \\
Home tools & 23 & $15.3 \%$ \\
Electronic gaming & 11 & $7.3 \%$ \\
Cosmetics and clothing & 34 & $20.6 \%$ \\
Total & 165 & $100 \%$ \\
\hline \hline
\end{tabular}

Table $\mathrm{X}$ shows the highest level of education of male are obtaining (Master-PHD) degree ratio (56.9\%), as it turns out that the highest level of education of females are receiving certificate (Diploma-bachelor) degree ratio (59.3\%), this demonstrates that the high educational level of sample search above the secondary education.
TABLE X

DISTRIBUTION OF RESPONDENTS ACCORDING TO EDUCATIONAL LEVEL AND GENDER VARIABLE

\begin{tabular}{lcccc}
\hline \hline Education level & $\begin{array}{l}\text { Male } \\
\text { Number }\end{array}$ & Ratio & $\begin{array}{l}\text { Female } \\
\text { Number }\end{array}$ & Ratio \\
\hline Secondary/High School & 6 & $6.9 \%$ & 7 & $10.9 \%$ \\
Diploma-bachelor & 31 & $36 \%$ & 38 & $59.3 \%$ \\
Master- PHD & 49 & $56.9 \%$ & 19 & $29.7 \%$ \\
Total & 86 & $100 \%$ & 64 & $100 \%$ \\
\hline \hline
\end{tabular}

Table XI shows that ratio $(40.7 \%)$ of respondents were male ranging in age (35-45), as it turns out that $(56.2 \%)$ of respondents are female between the ages of (45-55).

TABLE XI

DISTRIBUTION OF RESPONDENTS ACCORDING TO AGE AND GENDER VARIABLE

\begin{tabular}{lllll}
\hline \hline \multirow{2}{*}{ Age } & \multicolumn{2}{c}{ Male } & \multicolumn{2}{c}{ Female } \\
& Number & Ratio & Number & Ratio \\
\hline Less than 35 year & 15 & $17.4 \%$ & 11 & $17.1 \%$ \\
$35-45$ & 35 & $40.7 \%$ & 10 & $15.6 \%$ \\
$45-55$ & 18 & $20.9 \%$ & 36 & $56.2 \%$ \\
Great than 55 year & 18 & $20.9 \%$ & 7 & $10.9 \%$ \\
Total & 86 & $100 \%$ & 64 & $100 \%$ \\
\hline \hline
\end{tabular}

Table XII shows the more categories monthly income for male and female was in the class (900000-1200000) DI; this indicates that most respondents are high income, that high income owners represent the largest consumer Kurdish in using E. Shopping.

TABLE XII

DISTRIBUTION OF RESPONDENTS ACCORDING TO MONTHLY INCOME AND GENDER VARIABLE

\begin{tabular}{lllll}
\hline \hline \multirow{2}{*}{ monthly income } & \multicolumn{2}{c}{ Male } & \multicolumn{2}{c}{ Female } \\
& Number & Ratio & No. & Ratio \\
\hline Fro (300000-600000)DI & 8 & $9.3 \%$ & 6 & $9.4 \%$ \\
Fro (600000-900000) DI & 13 & $15.1 \%$ & 14 & $21.9 \%$ \\
Fro (900000-1200000) DI & 60 & $69.8 \%$ & 41 & $64.1 \%$ \\
More than 1200000 DI & 5 & $5.8 \%$ & 3 & $4.7 \%$ \\
Total & 86 & $100 \%$ & 64 & $100 \%$ \\
\hline \hline
\end{tabular}

Table XIII shows the average value of positive consumer trends search sample report (22.612), while the value of the average negative consumer trends (13.260), and this result reached by the average consumer trends survey positive words (13) expression, as well as the average negative words for consumer trends survey (9) expression. This result shows that the conduct members of the research sample positive oriented toward the electronic market.

TABLE XIII

POSITIVE AND NEGATIVE CONSUMER TRENDS TO THE SEARCH SAMPLE

\begin{tabular}{ll}
\hline \hline Consumer trend & Arithmetic mean \\
\hline Positive trend & 22.612 \\
Negative trend & 13.260 \\
\hline \hline
\end{tabular}

\section{A. First hypothesis}

There is a correlation between the questionnaire of electronic shopping in the information age and the components of the questionnaire on consumer trends of the sample members. 
Table XIV shows a matrix correlation between ages of the questionnaire that are statistically significant correlation, with correlation coefficient (0.867) abstract level (0.01). This indicates that the main variables tack the same positive direction.

TABLE XIV

MATRIX OF CORRELATION BETWEEN THE AGES OF THE ELECTRONIC SHOPPING QUESTIONNAIRE IN THE AGE OF INFORMATICS AND THE AXES OF THE HOUSEHOLD CONSUMPTION TRENDS QUESTIONNAIRE.

\begin{tabular}{|c|c|c|c|c|}
\hline Interviewer & $\begin{array}{l}\text { Behavioral } \\
\text { component }\end{array}$ & $\begin{array}{c}\text { Compon } \\
\text { ent of } \\
\text { knowled } \\
\text { ge }\end{array}$ & $\begin{array}{c}\text { Emotion } \\
\text { al } \\
\text { compon } \\
\text { ent }\end{array}$ & $\begin{array}{l}\text { respondents } \\
\text { in the } \\
\text { consumption } \\
\text { trends of the } \\
\text { member }\end{array}$ \\
\hline $\begin{array}{l}\text { Advantages and } \\
\text { disadvantages of } \\
\text { electronic } \\
\text { shopping }\end{array}$ & $0.953 * *$ & $0.742 * *$ & $0.845^{* *}$ & $0.786^{* *}$ \\
\hline Pre purchase & $0,846^{* *}$ & $0.757 * *$ & $0.726 * *$ & $0.851 * *$ \\
\hline $\begin{array}{l}\text { The actual } \\
\text { purchase phase }\end{array}$ & $0.609^{*}$ & $0,923 * *$ & $0.803 * *$ & $0.763^{* *}$ \\
\hline Post purchase & $0.913 * *$ & $0.624 * *$ & $0.872 * *$ & $0.798 * *$ \\
\hline $\begin{array}{l}\text { Steps involves in } \\
\text { e-shopping }\end{array}$ & $0.819^{* *}$ & $0.843 * *$ & $0.886^{* *}$ & $0.814 * *$ \\
\hline $\begin{array}{l}\text { e-commerce in } \\
\text { the information } \\
\text { age }\end{array}$ & $0.804 * *$ & $0.794 * *$ & $0.821 * *$ & $0.867^{* *}$ \\
\hline
\end{tabular}

\section{B. Second hypothesis}

There were statistically significant differences between the average scores of the sample on the advantages and disadvantages of electronic shopping to the variables: Education level of male and female, age, monthly income.

\section{Subsidiary hypothesis (2-1)}

There were statistically significant differences between the average scores of the sample on the advantages and disadvantages of electronic shopping to the variable of Education level of male and female.

Table XV shows that the F-value was (3.481 and 11.358) that is a statistical function value at $(0.01)$. Therefore, there was a statistically significant relation between the variables.

TABLE XV

ANOVA TABLE FOR THE SAMPLE GRADES IN THE AXIS ADVANTAGES AND DISADVANTAGES OF E- SHOPPING TO THE VARIABLE OF EDUCATION LEVEL OF MALE AND FEMALE.

\begin{tabular}{|c|c|c|c|c|c|}
\hline Male education & $\begin{array}{l}\begin{array}{l}\text { Sum of } \\
\text { squares }\end{array} \\
\end{array}$ & $\begin{array}{l}\text { Mean } \\
\text { square }\end{array}$ & df & $\mathrm{F}$ & Sig. \\
\hline Between groups & 3194.268 & 1597.134 & 2 & 3.48 & \multirow{3}{*}{0.01} \\
\hline Within groups & 67441.162 & 458.783 & \multirow[t]{3}{*}{147} & \multirow[t]{3}{*}{1} & \\
\hline Total & 70635.43 & 2055.917 & & & \\
\hline Female education & & & & & \multirow{4}{*}{0.01} \\
\hline Between groups & 4221.674 & 2110.837 & 2 & \multirow{3}{*}{$\begin{array}{l}11.3 \\
58\end{array}$} & \\
\hline Within groups & 27319.309 & 185.846 & \multirow[t]{2}{*}{147} & & \\
\hline Total & 31540.983 & 2296.683 & & & \\
\hline
\end{tabular}

DOI: $10.25156 /$ ptjhss

\section{Subsidiary hypothesis (2-2)}

There were statistically significant differences between the average scores of the sample on the advantages and disadvantages of electronic shopping to the variable of age.

Table XVI show that the F-value is (28.817 and 13.961) that is a statistical function value at $(0.01)$. Therefore, there was a statistically significant relation between the variables.

TABLE XVI

ANOVA TABLE FOR THE SAMPLE GRADES IN THE AXIS ADVANTAGES AND DISADVANTAGES OF E-SHOPPING TO THE VARIABLE OF AGES OF MALE AND FEMALE.

\begin{tabular}{|c|c|c|c|c|c|}
\hline Age of male & $\begin{array}{l}\text { Sum of } \\
\text { squares }\end{array}$ & $\begin{array}{l}\text { Mean } \\
\text { square }\end{array}$ & df & $\mathrm{F}$ & Sig. \\
\hline Between groups & 6293.641 & 2097.880 & 3 & \multirow{2}{*}{28.817} & \multirow{2}{*}{0.01} \\
\hline Within groups & 10629.382 & 72.801 & 146 & & \\
\hline Total & 16923.023 & 2170.681 & & & \\
\hline Age of female & & & & \multirow{4}{*}{13.961} & \multirow{4}{*}{0.01} \\
\hline Between groups & 2564.315 & 854.772 & 3 & & \\
\hline Within groups & 8938.725 & 61.227 & 146 & & \\
\hline Total & 11503.04 & 915.999 & & & \\
\hline
\end{tabular}

\section{Subsidiary hypothesis (2-3}

There are statistically significant differences between the average scores of the sample on the advantages and disadvantages of electronic shopping to follow variable of monthly income.

Table XVII shows the F-value is (45.616and 44.941) that the statistical function value at $(0.01)$. Therefore, there was a statistically significant relation between the variables.

TABLE XVII

ANOVA TABLE FOR THE SAMPLE GRADES IN THE AXIS ADVANTAGES AND DISADVANTAGES OF E- SHOPPING TO THE VARIABLE OF MONTHLY INCOME OF MALE AND FEMALE.

\begin{tabular}{|c|c|c|c|c|c|}
\hline $\begin{array}{l}\text { Monthly income } \\
\text { (male) }\end{array}$ & $\begin{array}{l}\begin{array}{l}\text { Sum of } \\
\text { squares }\end{array} \\
\end{array}$ & $\begin{array}{l}\text { Mean } \\
\text { square }\end{array}$ & df & $\mathrm{F}$ & Sig. \\
\hline Between groups & 6552.890 & 2184.297 & 3 & \multirow{4}{*}{45.616} & \multirow{4}{*}{0.01} \\
\hline Within groups & 6991.094 & 47.884 & 146 & & \\
\hline Total & 13543.98 & 2232.181 & & & \\
\hline $\begin{array}{l}\text { Monthly } \\
\text { income(female) }\end{array}$ & & & & & \\
\hline Between groups & 5432.780 & 1810.927 & 3 & \multirow{3}{*}{44.941} & \multirow{3}{*}{0.01} \\
\hline Within groups & 5881.123 & 40.281 & 146 & & \\
\hline Total & 11313.9 & 1851.208 & & & \\
\hline
\end{tabular}

\section{Third Hypothesis}

There were statistically significant differences between the average scores of the sample in regards to the steps involved in online shopping in the information age according to the variables: (education level of male and female, age, monthly income).

\section{Subsidiary hypothesis (3-1)}

There were statistically significant differences between the averages scores of the sample in regards to the steps involved in online shopping in the information age according to the variable: education level of male and female. 
Table XVIII shows that the F-value is (14.277 and 11.283) that is a statistical function value at $(0.01)$. Which indicate that there are significant relations between the variable.

TABLE XVIII

ANOVA TABLE SHOWS THE STEPS INVOLVED IN ONLINE SHOPPING IN THE INFORMATION AGE ACCORDING TO THE VARIABLE: EDUCATION LEVEL OF MALE AND FEMALE.

\begin{tabular}{llllll}
\hline \hline Male education & $\begin{array}{l}\text { Sum of } \\
\text { squares }\end{array}$ & $\begin{array}{l}\text { Mean } \\
\text { square }\end{array}$ & df & F & Sig. \\
\hline Between groups & 9404.732 & 4702.366 & 2 & 14.277 & 0.01 \\
$\begin{array}{l}\text { Within groups } \\
\text { Total }\end{array}$ & $\begin{array}{l}48418.298 \\
57823.03\end{array}$ & $\begin{array}{l}329.376 \\
5031.742\end{array}$ & 147 & & \\
$\begin{array}{l}\text { Female } \\
\text { education }\end{array}$ & & & & & \\
Between groups & 8568.263 & 4284.131 & 2 & & \\
$\begin{array}{l}\text { Within groups } \\
\text { Total }\end{array}$ & 55814.805 & 379.694 & 147 & 11.283 & 0.01 \\
\hline \hline
\end{tabular}

\section{Subsidiary hypothesis (3-2)}

There is significant difference between the average scores of the sample in regards to the steps involved in online shopping in the information age according to the follow variable: age.

Table XIX shows that the F-value is (16.643 and 5.106) the statistical function value at (0.01). Therefore, there is a statistically significant relation between the variables.

TABLE XIX

ANOVA TABLE FOR THE SAMPLE GRADES IN THE STEPS INVOLVE IN ONLINE SHOPPING IN THE INFORMATION AGE ACCORDING TO THE VARIABLE: AGE OF MALE AND FEMALE.

\begin{tabular}{llllll}
\hline \hline $\begin{array}{l}\text { Age of } \\
\text { male }\end{array}$ & $\begin{array}{l}\text { Sum of } \\
\text { squares }\end{array}$ & $\begin{array}{l}\text { Mean } \\
\text { square }\end{array}$ & df & F & Sig. \\
\hline $\begin{array}{l}\text { Between } \\
\text { groups }\end{array}$ & 7828.521 & 2609.507 & 3 & & \\
$\begin{array}{l}\text { Within } \\
\text { groups }\end{array}$ & 22891.950 & 156.794 & 146 & & 0.01 \\
$\begin{array}{l}\text { Total } \\
\text { Age of }\end{array}$ & 30720.471 & 2766.301 & & & \\
$\begin{array}{l}\text { female } \\
\text { Between } \\
\text { groups }\end{array}$ & 4364.158 & 1454.718 & 3 & & \\
$\begin{array}{l}\text { Within } \\
\text { groups }\end{array}$ & 41598.867 & 284.924 & 146 & & \\
Total & 45963.025 & 1739.642 & & & \\
\hline \hline
\end{tabular}

\section{Subsidiary hypothesis (3-3)}

There are statistically significant differences between the averages scores of the sample in regards to the steps involves in online shopping in the information age according to variable: monthly income.

Table XX shows that the F-value was (4.209and 6.556) that is a statistical function value at (0.01). Therefore, there is a statistically significant relation between the variables.
TABLE XX

ANOVA TABLE FOR THE SAMPLE GRADES IN THE STEPS INVOLVED IN ONLINE SHOPPING IN THE INFORMATION AGE ACCORDING TO THE FOLLOW VARIABLE (MONTHLY INCOME OF MALE AND FEMALE) .

\begin{tabular}{llllll}
\hline \hline $\begin{array}{l}\text { Monthly } \\
\text { income (male) }\end{array}$ & $\begin{array}{l}\text { Sum of } \\
\text { squares }\end{array}$ & $\begin{array}{l}\text { Mean } \\
\text { square }\end{array}$ & df & F & Sig. \\
\hline $\begin{array}{l}\text { Between } \\
\text { groups }\end{array}$ & 1347.754 & 449.251 & 3 & 4.209 & 0.01 \\
$\begin{array}{l}\text { Within groups } \\
\text { Total }\end{array}$ & 15582.742 & 106.731 & 146 & & \\
$\begin{array}{l}\text { Monthly } \\
\text { income(female) }\end{array}$ & & 555.982 & & & \\
$\begin{array}{l}\text { Between } \\
\text { groups }\end{array}$ & 2247.554 & 749.185 & 3 & 6.556 & 0.01 \\
$\begin{array}{l}\text { Within groups } \\
\text { Total }\end{array}$ & 16682.842 & 114.266 & 146 & & \\
\hline \hline
\end{tabular}

\section{Fourth Hypothesis}

The degrees to which the different factors affect online shopping are different from one factor to another in the information age.

Table XXI shows the independent variables are more influential than others on a variable of electronic shopping in the age of informatics as a dependent variable, priority is as follows:

1- Male education variable ratio $(80.5 \%)$

2- Female education variable ratio $(70.6 \%)$

3- Monthly income for male variable ratio $(62.1 \%)$

4- Age for male variable ratio $(53.4 \%)$

It got a variable level of male and female education at first and second place respectively. This indicates that, this category has a high cultural level which practices electronic shopping. The advantages offered by their ability to protect themselves from defects and risks. It got a variable monthly income on the third place, let us all realize the important role played by the monthly income in determining of their push on the practice of electronic shopping in particular, because the electronic procurement process may require the freight and deliver which adds more value to the basic product which makes higher prices in some cases from the original price .Either variable male age got the fourth place; this is due to the experience factor not only through repeated testing and constant practice.

TABLE XXI

RELATIVE IMPORTANCE USING REGRESSION COEFFICIENT FOR FACTORS INFLUENCING ELECTRONIC SHOPPING IN THE AGE OF INFORMATICS

\begin{tabular}{|c|c|c|c|c|c|c|c|}
\hline $\begin{array}{l}\text { Independent } \\
\text { variable }\end{array}$ & $\begin{array}{l}\text { Corr } \\
\text { elati } \\
\text { on } \\
\text { coef } \\
\text { ficie } \\
\text { nt }\end{array}$ & $\begin{array}{l}\text { Parti } \\
\text { cipat } \\
\text { ion } \\
\text { rate }\end{array}$ & $\mathrm{F}$ & Sig & $\begin{array}{l}\text { Regres } \\
\text { sion } \\
\text { coeffici } \\
\text { ent }\end{array}$ & $\mathrm{T}$ & Sig \\
\hline Male & 0.86 & 0.80 & 110.9 & 0.0 & \multirow{2}{*}{0.652} & \multirow{2}{*}{9.677} & 0.0 \\
\hline education & 0 & 5 & 18 & 1 & & & 1 \\
\hline Female & 0.85 & 0.70 & 62.23 & 0.0 & \multirow{2}{*}{0.492} & \multirow{2}{*}{7.199} & 0.0 \\
\hline education & 0 & 6 & 1 & 1 & & & 1 \\
\hline Monthly & 0.78 & 0.62 & 40.96 & 0.0 & \multirow{2}{*}{0.343} & \multirow{2}{*}{7.680} & 0.0 \\
\hline $\begin{array}{l}\text { income for } \\
\text { male }\end{array}$ & 2 & 1 & 8 & 1 & & & 1 \\
\hline \multirow[t]{2}{*}{ Age for male } & 0.74 & 0.53 & 27.33 & 0.0 & \multirow{2}{*}{0.431} & \multirow{2}{*}{5.969} & 0.0 \\
\hline & 1 & 4 & 9 & 1 & & & 1 \\
\hline
\end{tabular}




\section{E. Fifth Hypothesis}

The degree to which the different factors affect consumption trends of the member is different from one factor to another.

Table XXII shows the independent variables are more influential than others on a variable affect consumption trends of the member as a dependent variable, priority is as follows:

1. Female education $(86.1 \%)$

2. Monthly income for male $(76.5 \%)$

3. Male education (69\%)

4. Age for female $(61.2 \%)$

The most influential variable was female education; this means that the level of education is more influential in consumer trends for more responsive to emotional effects. Monthly income variable obtained second rank, income affect the acceptance or rejection, by a product based on its price and cost. Then the third ranked male education variable the level of male education and information about the products and how they perceive their products affect consumer trends.

TABLE XXII

RELATIVE IMPORTANCE USING REGRESSION COEFFICIENT FOR FACTORS INFLUENCING CONSUMER TREND

\begin{tabular}{|c|c|c|c|c|c|c|c|}
\hline $\begin{array}{l}\text { Indepen } \\
\text { dent } \\
\text { variable }\end{array}$ & $\begin{array}{l}\text { Correl } \\
\text { ation } \\
\text { coeffi } \\
\text { cient }\end{array}$ & $\begin{array}{l}\text { Parti } \\
\text { cipat } \\
\text { ion } \\
\text { rate }\end{array}$ & F & Sig. & $\begin{array}{l}\text { Regre } \\
\text { ssion } \\
\text { coeffi } \\
\text { cient }\end{array}$ & $\mathrm{T}$ & Sig. \\
\hline $\begin{array}{l}\text { Female } \\
\text { education }\end{array}$ & 0.772 & 0.861 & 78.971 & 0.01 & 0.695 & 8.344 & 0.01 \\
\hline $\begin{array}{l}\text { Monthly } \\
\text { income } \\
\text { for male }\end{array}$ & 0.713 & 0.765 & 64.681 & 0.01 & 0.578 & 6.385 & 0.01 \\
\hline $\begin{array}{l}\text { male } \\
\text { education }\end{array}$ & 0.668 & 0.690 & 54.683 & 0.01 & 0.433 & 5.353 & 0.01 \\
\hline $\begin{array}{l}\text { Age for } \\
\text { female }\end{array}$ & 0.615 & 0.612 & 39.233 & 0.01 & 0.413 & 4.514 & 0.01 \\
\hline
\end{tabular}

\section{F. Sixth Hypothesis}

The relative weights assigned to the priority of the consumption trends are different from one another in the research sample.

Table XXIII shows the priority a component of consumer trends among respondents (male) was as follows:

1- Component of knowledge ratio (36.5\%)

2- Behavioral component ratio (34\%)

3- Emotional component ratio (29.4\%)

Table XXIII shows the priority a component of consumer trends among respondents (female) was as follows:

1- Emotional component ratio (35.6\%)

2- Component of knowledge ratio $(34.1 \%)$

3- Behavioral component ratio (30.3\%)

The Results showed that the knowledge component of consumer trends was the first influential male search sample, this suggests that males in general tempt for reasoning and analytical qualities of things. As the results showed that the emotional component of consumer trends was the first influential female search sample, this suggests that the females in general characterized by the passion that influence their behavior.
TABLE XXIII

RELATIVE WEIGHTS TO THE PRIORITY COMPONENTS OF THE CONSUMER TREND IN THE RESEARCH SAMPLE

\begin{tabular}{|c|c|c|c|c|c|c|}
\hline \multirow[b]{2}{*}{ Component } & \multicolumn{3}{|c|}{ Male } & \multicolumn{3}{|c|}{ Female } \\
\hline & $\begin{array}{l}\text { Rela } \\
\text { tive } \\
\text { weig } \\
\text { ht }\end{array}$ & $\begin{array}{c}\text { Perc } \\
\text { enta } \\
\text { ge } \\
\% \\
\end{array}$ & $\begin{array}{l}\text { pre } \\
\text { par } \\
\text { ati } \\
\text { on }\end{array}$ & $\begin{array}{c}\text { Relativ } \\
\text { e } \\
\text { weight }\end{array}$ & $\begin{array}{l}\text { Percent } \\
\text { age } \%\end{array}$ & preparation \\
\hline $\begin{array}{l}\text { behavioral } \\
\text { component }\end{array}$ & 385 & $34 \%$ & $\begin{array}{l}\text { Sec } \\
\text { on } \\
d\end{array}$ & 312 & $30.3 \%$ & Third \\
\hline $\begin{array}{c}\text { component } \\
\text { of } \\
\text { knowledge }\end{array}$ & 413 & $\begin{array}{c}36.5 \\
\%\end{array}$ & $\begin{array}{l}\text { Fir } \\
\text { st }\end{array}$ & 351 & $34.1 \%$ & Second \\
\hline $\begin{array}{l}\text { emotional } \\
\text { component }\end{array}$ & 333 & $\begin{array}{c}29.4 \\
\%\end{array}$ & $\begin{array}{l}\text { Thi } \\
\text { rd }\end{array}$ & 366 & $35.6 \%$ & First \\
\hline Total & 1131 & & & 1029 & & \\
\hline
\end{tabular}

\section{The FUtURE OF E. MARKETING}

The great progress that we are witnessing at all technological and digital levels in the process of organizing the products that are displayed on the Internet, and perhaps this has become an evident matter to all network users, and thanks to the progress also, different digital commercial platforms can direct users to the products they are looking for based on their data; As a number of economic experts predict that e-commerce in the world has a bright future; Due to the large purchasing power of individuals and customers and the widespread use of the Internet.

Since the outbreak of the Coronavirus (Coved 19), more than $85 \%$ of customers around the world are shopping via the Internet, so there is no doubt that despite the setbacks in various sectors around the world; On top of them are the commercial sectors, but there are many other sectors that have made the most of this crisis, and perhaps the most prominent of them is "e-commerce", which has witnessed an increasing demand in light of customers' fear of being in crowded places.

We all know how electronic shopping processes take place and how customers conduct marketing rounds to obtain products or services electronically via the Internet, but what about the role of artificial intelligence in such transactions? A number of experts and specialists in the world of technology predict that the next few years will witness positive intervention from artificial intelligence techniques.

\section{WHAT ARE THE DRAWBACKS?}

The biggest challenge facing e-shopping companies is how to reach the critical mass of consumers who prefer or find buying from realistic stores, not virtual ones, a better option, in terms of the ability to experiment with goods, know their features and texture, and try to reduce their price, and here lies the challenge and the role of creative ideas.

\section{CONCLUSIONS}

The average positive and negative expressions were found to be 22.612 , while the negative average was 13,260 . This finding indicates that the knowledge received by respondents 
through the Internet has developed good ideas and beliefs about the goods and services offered.

As shown in Table XIV there was a direct correlation between the electronic shopping in the information age and the consumptions trends of a member. The value of the correlation coefficient was (0.867). This result indicates that in the case of the sample members to practice e-shopping and browsing the various selling sites on the Web and the amount of information received by the browser for these sites and facts and ideas about what is marketed goods and services have a significant positive impact on consumer trends.

It was clear from the results of the Tables XV, XVI and XVII that there are statistically significant differences between the average scores of the sample in the advantages and disadvantages of e-marketing according to variables (education, age, monthly income). They are more aware of the advantages and disadvantages of e-marketing, because of the environment to which they belong and the social nature that is often more informed and use of the Internet environment.

Data analysis shows that there are statistically significant differences between the average scores of the sample in consumer trends, because consumers make up their attitudes towards the goods and services offered in the internet based on their income level and their perception of their features and need a wide knowledge in various scientific fields.

To achieve the fourth hypothesis, the relative importance was calculated using the regression coefficient of the factors influencing e-marketing. Table XXI shows that there are independent variables that are more influential than others on the e-marketing variable: education of the male by $80.5 \%$, followed by education of the female by $70.6 \%$, at number three was the monthly income by $62.1 \%$ and finally at number four was age for male by $53.4 \%$. It got a variable level of male and female education at first and second place respectively. This indicates that, this category has a high cultural level which practices electronic shopping. The advantages offered by their ability to protect themselves from defects and risks.

The rate of participation of factors influencing consumer trends varied according to the following order: education of the female by $86.1 \%$, followed by monthly income by $76.5 \%$, at number three was the education level of the male by $69 \%$, and finally on fourth was age of the female by $61.2 \%$. This indicates that the level of education of females is more influential in their consumption trends to increase their response to emotional stimuli, and income affects the acceptance or refusal to buy a particular product based on its price and cost.

The results in Table XXIII showe that the cognitive component of consumer trends was the first influencer in males, and the emotional component was the first influencer in females. This indicates that males in general are characterized by logical and analytical thinking of things, and females in general are characterized by emotion that plays on their actions.

\section{REFERENCES}

Adam Grzywaczewski, Rahat Iqbal, Nazaraf Shah (2010). Anne James, E-Marketing Strategy for Businesses, Conference: e-
Business Engineering (ICEBE), 2010 IEEE 7th International Conference.

Anuja Bokhare and Pravin Metkewar, (2015). State-of-the-Art: EMarketing Types, Practices, Emerging Trends and Technologies, International Association of Scientific Innovation and Research (IASIR) (An Association Unifying the Sciences, Engineering, and Applied Research), Vol. 11, No. 1, December 2014-February 2015.

Brich, A ., Gerbert, P. \& Schneider, D . (2000) The age of e. tail conquering the new world of electronic shopping. Oxford, UK: Capstone : Publishing Limited.

Brown, Mark, et.,al . (2003) Buying or browsing: An shopping orientations and online purchase intention. European journal of Marketing, MCB university Press, Vol. 37, No. 11-12.

Brown, Mark, et, al. (2003). Buying or browsing: An shopping orientations and online purchase intention. European journal of Marketing. MCB university Press, Vol.37, No.11-12.

Constantinides , Efthymios . (2004) Influencing the Online Consumer's Behavior: The Web Experience._Internet Research MCB university press, Vol.14, No.2.

Dan J. Kim, Donald L. \& Ferrin, H. and Raghav Rao. (2003) TRUST AND SATISFACTION, TWO STEPPING STONES FORSUCCESSFUL E-COMMERCE RELATIONSHIPS: $A$ LONGITUDINAL EXPLORATION, for publication in Information Systems Research, An early version of this paper was awarded best paper runner-up at ICIS.

Jayawardhena, Chanaka. (2004) Personal Values Influences on EShopping Attitude and Behavior. Internet Research, MCBuniversity press, Vol. 14, No. 2.

Kotler, Philip P . (2007) Marketing Management, Northwestern University.

Littlefield, J. E, Bao,y \& Cook D. L. (2000) Internet Real Estate Information: Are Home Purchase Paying Attention toit. Journal Of Consumer Marketing, Vol.17, No.7.

Michael, Hutt \& Thomas , Speh .(2007) Business Marketing Management, Arizona state University \& Miami University, 2007.

Miley, K. (2001) Perceived risk for shopping via the internet among US. Consumers. Texas: Graduate school of the Texas woman's university college of arts and sciences.

Modal, M. (2000) Now or Never: How Companies Must change today to win the Battle for Internet consumers, N. Y. Harper Business.

Monsuwe, Tonita PereaY.,et al. (2004) What Drives Consumersto shop Online. International Journal of services industry management, MCB university press, Vol. 15, No.1.

Phau, Ian \& Poon, Sui M. (2000)_Factors Influencing the Types of Products and services Purchased Over. The Internet. Internet Research and Colon: Electronic Networking Applications and Policy, Vol.10,No.2 .

Rath, R. C., \& Samal, M. S. (2013). An Overview of E-Commerce Practices of Marketing on Supply Chain Management in India: Emerging Business Opportunities and Challenges. International Journal of Supply Chain Management, Vol.2, No.2.

Shankar, V., Venkatesh, A., Hofacker, C., \& Naik, P. (2010). Mobile marketing in the retailing environment: current insights and 
future research avenues. Journal of interactive marketing, Vol. 24, No. 2.

Smutkupt, P., Krairit, D., \& Esichaikul, V. (2010). Mobile marketing: Implications for marketing strategies. International Journal of Mobile Marketing, Vol. 5, No. 2.

Teo,Thompson . (2001) Demographic An MotivationVariables Associated With Internet Usage Activities. Internet Research: Electronic Networking Applications and Policy Vol.11, No.2 .

Tsiotsou, R. H., \& Vlachopoulou, M. (2011). Understanding the effects of market orientation and e-marketing on service performance. Marketing Intelligence \& Planning, Vol.29, No.2.
Vrechopoulos , A . p. Siomkos , GJ. \& Doukidis , G . I. (2001) Internet Shopping Adoption by Geerk Consumers, European journal of innovation Management, Vol 4. No.3.

Ward, Michael, R. \& Lee, Michael, J.(2001) internet shopping consumer search and branding. The journal of Product \& BrandManagement, Vol.9, No. 1.

Wolfinbarger, M \& Gilly, M. (2002) Shopping Online for freedom, control and fun, California Management Review, Vol. 43, No. 2.

Wolin, Lori, D. \& Korgaonkar, Pradeep . (2003) Web Advertising: Gender Differences in Beliefs, Attitudes and behavior. Internet Research: Electronic Application and policy, MCB university press, Vol. 13 , No.5. 